\title{
THE SONG OF IOPAS
}

The Song of Iopas plays an important part in the development of the relationship between Dido and Aeneas. There is no symbolism in the Song and no attempt to arouse Roman prejudice against the Carthaginians.

At the end of Book I of Virgil's Aeneid Dido gives a banquet for Aeneas and other Trojans. Part of the entertainment is a song by the minstrel Iopas. His performance is described thus (740-7):

personat aurata, docuit quem maximus Atlas.

hic canit errantem lunam solisque labores,

unde hominum genus et pecudes, unde imber et ignes,

Arturum pluuiasque Hyadas geminosque Triones,

quid tantum Oceano properent se tingere soles

hiberni, uel quae tardis mora noctibus obstet;

ingeminant plausu Tyrii, Troesque sequuntur.

There are other famous songs by minstrels in ancient epic. In the first book of the Odyssey Phemius sings of the return of the Greeks from Troy, whilst in the eighth Demodocus tells the story of the Wooden Horse and other tales of Troy, as well as the scandalous story of Aphrodite and Ares ${ }^{1}$. In the Argonautica (I 496f) Apollonius Rhodius makes Orpheus sing of the Creation of the World. Some of these themes would have been unsuitable for Iopas, though the reasons given as to why they are unsuitable are not always convincing ${ }^{2}$. The need for variety

1 This was allegorised into a cosmological exposition of the universe and in this way may possibly have indirectly suggested Virgil's theme. See R. R. Schlunk, The Homeric Scholia and the Aeneid, Ann Arbor, 1974, p. 33.

2 E. g. R. G. Austin in P. Vergili Maronis Aeneidos Liber Primus, Oxford, 197 I on I $74^{2 \mathrm{ff}}$ thinks a tale of Trojan defeat and suffering would have been tactless. But the Trojans did have some successes which Iopas could have sung about.

6 
would have prevented Virgil from making Iopas sing of the fighting at Troy, the Wooden Horse or the return of the Greeks. Fighting at Troy is the theme of the scenes on the Temple of Juno (I 453-93). In Book II there is more fighting at Troy and the story of the Wooden Horse, whilst Books I and III are concerned with the travels of the Trojans and make much use of material from the Odyssey on the travels of Odysseus. As for the story of Ares and Aphrodite, it is too sweeping to say that scandal about the gods has no place in Virgilian epic ${ }^{1}-$ the amours even of Jupiter himself are alluded to (IV r97, XII r43-5) ${ }^{2}-$ but such scandal was hardly a suitable theme for a song in the presence of Dido with her strict views on fidelity in marriage. There are then reasons against the other themes which have been mentioned, but are there any reasons for a song on the theme which Virgil has chosen for Iopas, since there were obviously other subjects available?

First the picture of the Universe given by Iopas provides an impressive background against which the story of Dido and Aeneas, and indeed that of the agonies of the fall of Troy, can be told. A number of times in the Aeneid when Virgil is dealing with human emotions he sets them against the backcloth of an uncaring Nature, e. g. in IV 80-I, 52I-7. However the song has a more important contribution to make. To see what it is, we must look at earlier happenings in Book I. After his speech to Venus, Jupiter dispatches Mercury to Carthage to make sure that Dido will be friendly towards the Trojans. Dido is friendly. In a speech to Ilioneus $(562-78)$, after apologising for the hostility of her coastguards, she offers help; she will either assist the Trojans on their way or give them a place in her kingdom on equal terms with the Carthaginians, though she leaves no doubt that she will be the ruler of the combined peoples (574). Jupiter has of course intervened, but on the other hand the gods in the Aeneid do not normally make men behave in a way that is out of character or unnatural to them. Here both natural compassion (630) and statesmanship provide motives for her offer of a permanent home. Anna later points out (IV $3^{\mathrm{I}-49)}$ that Dido is surrounded by powerful tribes, she refuses to ally herself in marriage with one of their leaders and there is the possibility of an attack from her brother in Tyre. Dido needs all the military help she can get.

1 So Austin on $1742 \mathrm{ff}$.

- Commentators also point out the eroticism which Virgil appears to introduce deliberately into the Venus-Vulcan scene in Book VIII. See e. g. M. A. Di Cesare, The Altar and the City, New York \& London, 1974, p. I5of. 
For their part, the 'Trojans do not yet commit themselves. Ilioneus' request $\left(55^{2}\right)$ to be allowed to prepare timber to repair their ships might be taken to imply a lengthy stay, since the timber would need time to season, but negotiations are broken off by the appearance of Aeneas and, apart from thanks, Aeneas' speech contains only an indefinite reference (6ro) to the resumption of his travels. This is the situation when Iopas begins his song, though Dido's lavish hospitality in the meantime must have further increased the Trojans' desire to stay, whilst on their side the Carthaginians had time to be impressed by Aeneas himself, beautified by Venus $(589-93)$, and by his splendid gifts (709-II). Amid the good cheer of the banquet, Iopas sings of a Universe of toil and uncertainty, hostile to men and in particular hostile to men sailing the sea at the time which was either already present or fast approaching. Iopas sings too of the origin of men and beasts, a theme which must with this background have given his audience a feeling of the unity of animate as against inanimate nature and in particular of the unity of men, whether Trojans or Carthaginians. The Trojans had been given an offer of hospitality by Dido and this song would clearly encourage them to make full use off it. As for the Carthaginians, if Dido's offer had been unpopular with them, they would surely have given this song a lukewarm reception. As it is, ingeminant plausu (747). The Trojans wait to see the reaction of their hosts but then Troesque sequuntur, an indirect indication of their desire to winter in Carthage. Later (IV 295) the Trojans are glad to get away from Carthage and Dido has alienated her Carthaginians by her behaviour (IV 32I), but at the banquet, as the result of Iopas' song, the friendly feeling between the two sides is at its height and the pressure is strong on Aeneas to agree to a lengthy stay.

If this interpretation is correct, the song of Iopas marks an important stage in the affair of Dido and Aeneas. Dido has begun to love Aeneas, thanks to the machinations of Venus and Cupid. Now she has been given good reason to hope that he will be with her over the winter and it is only after the song that we are told of her love for Aeneas influencing her actions. What evidence is there that this is how Virgil intended the song to be taken? The song is an adaptation of lines at Georgics II 477-82. There Virgil prays for the assistance of the Muses:

caelique uias et sidera monstrent,

defectus solis uarios lunaeque labores;

unde tremor terris, qua ui maria alta tumescant 
obicibus ruptis rursusque in se ipsa residant, quid tantum Oceano properent se tingere soles hiberni, uel quae tardis mora noctibus obstet.

The differences in the Aeneid passage are all significant. Some will be considered later but here it may be noted that Virgil adds to the impression of toil and trouble conveyed by the word labores, that of uncertainty by substituting errantem for defectus. He also removes the lines which refer to earthquakes and their consequences. These are primarily land disasters and not of regular occurrence and Virgil is concerned to remind his audience of the normal dangers of sea-travel. He puts in instead a line saying Iopas told of the origins of men, beasts, and imber et ignes, so the background becomes not only the frightening immensity of space but that of time as well and the words imber et ignes ${ }^{1}$ should remind the reader, as presumably the Trojans were reminded, of the storm at the beginning of Book I (cf. e. g. 90, I23). Another important change is the introduction of 744 :

\section{Arcturum pluuiasque Hyadas geminosque Triones,}

This line appears again at III $5 \mathrm{r} 6$, where Palinurus, Aeneas' pilot, is surveying the sky to see whether the weather is suitable for sailing. Arcturus, the Hyades and the Triones were all important for navigation. The rising and setting of Arcturus, at the beginning of September and the end of October respectively, were periods of storm. The evening rising (late October) and morning setting (November) of the Hyades indicated rain. The Great and Little Bears were important for steering and in stormy weather the stars could not be seen (cf. III 204: sine sidere noctes) ${ }^{2}$. The last two lines in this context further draw attention to the difficulties of sea-travel in the autumn and winter.

A further argument that this is the correct interpretation of Iopas' song and its effect may be derived from Dido's behaviour. Lines 748-9 describe its effect on her:

nec non et uario noctem sermone trahebat infelix Dido longumque bibebat amorem.

1 Austin on 1743 takes imber et ignes to refer to the elements water and fire. But in that case why are only two elements mentioned? In the passages Austin cites all four appear and ignis is, as expected, in the singular.

2 See Austin's note on I 744 . 
Austin translates the last words by 'drinking in long draughts of love'. It is doubtful whether the words can mean this. In support Austin quotes III 487: longum Andromachae testentur amorem, but there longum simply means 'long-lasting' as it does also at Catullus 76,13 : longum deponere amorem, which Austin also quotes. This is the meaning it should be given here. It might be objected that Dido's love was not long-lasting, that within a few months or weeks Aeneas was to abandon her, but longum here is not used objectively but with empathy to convey Dido's feelings ${ }^{1}$. She had not known how long Aeneas would stay - it might only be a matter of days - and now a stay over winter looked a probability. This seemed long compared to her former expectation and in her relief she indulges her feelings, just as she is later to indulge them even more after Anna's speech at the beginning of Book IV (cf. IV 54-5). Virgil makes it clear that the reason for Dido's questions about Troy is that she wants to keep Aeneas beside her and will listen to the same stories over and over again (IV $78 \mathrm{f}$ ). This may explain why she does not appear to have been influenced by Aeneas' account of the oracles about his mission; his narrative was largely just a pretext for keeping him with her.

One other question is worth raising. Are we to suppose that Iopas intended his song to have the effect it did have? We can argue that Iopas is no common minstrel. He has been taught by maximus Atlas and his song deals with what Virgil appears to think the highest theme for poetry (Georgics II 475f). He is a uates and like Orpheus in the Argonautica, who strikes up to prevent a quarrel, Iopas can produce the song the situation requires ${ }^{2}$. He presumably realises the military situation. He may also have recognised from Aeneas' extravagant speech of thanks (595f) his incipient love for the queen, and Dido's behaviour $(717-8)$ has indicated some liking at least for Aeneas' son. A union between the two looked a possibility and would bring some obvious advantages. But such a union required time for the relationship to mature. Dido was determined to remain faithful to Sychaeus and Aeneas seemed bent on going to Italy. Moreover such a union would have to be acceptable to the followers of both parties. Iopas

1 Some of the meaning which Austin wants the phrase longumque bibebat amorem to have is conveyed by the tense and also by the contrast with Dido's literal drinking in 737 : summo tenus attigit ore. Her abstemiousness there is emphasised by the contrast with Bitias.

2 The reason for Orpheus' choice of subject is presumably to make his listeners' quarrel seem trivial against the background of Nature. 
therefore may have devised a song which at one and the same time puts forward reasons why the Trojans should delay their departure and tests Carthaginian and Trojan feelings towards each other. The banquet when leaders of both parties were present was a good opportunity for such a test and the time when, amid the geniality and good fellowship, a favourable reaction was most likely. Such an argument however must be speculative. Virgil does not provide the evidence for a definite conclusion, although the emphasis of the song makes it tempting.

Does the Song of Iopas have any symbolic significance? It has been maintained that it does ${ }^{1}$. However the initial reason for giving it a symbolic significance was that it did not appear to have much nonsymbolic significance that was relevant to its context. If it can be shown to have an important non-symbolic significance, then the need to give it a symbolic significance disappears. However though the need disappears, that does not necessarily mean that a symbolic significance is not present as well. The theory that has found favour recently is that the moon symbolises Dido and the sun Aeneas. To start with one point needs making. Such symbolism cannot have been introduced into the song by Iopas himself for two reasons. First, its detection depends on the reader being familiar with Virgil's comparison of Dido to Diana (I 498f) and possibly also with his comparison of Aeneas to Apollo (IV I43f). Secondly, Iopas would hardly have referred, as this view makes him, in a public performance even symbolically to a possible love affair between Dido and Aeneas. That would have offended the widow of Carthage even more than a song about the amours of Venus and Mars would have done. The symbolism, if any, must reside solely in Virgil's summary. Is there any?

It can be argued with some plausibility that the moon and sun in 742 do symbolise Dido and Aeneas; Dido has already been compared to Diana and Aeneas is later to be compared to Apollo. The moon is described as errantem and Dido herself is described as errans in IV $2 \mathrm{II}$. If errantem hints at Dido, then even more strongly would labores hint at Aeneas, since the word is often applied to Aeneas' travels, and it could be argued that Virgil has changed the phrase defectus solis of

1 See V. Pöschl. The Art of Vergil, Eng. transl. by G. Seligson, Ann Arbor, I962, p. I52f. 
Georgics II 478 in order to get a stronger link with Aeneas. However the words errantem and labores do not contrast Dido and Aeneas since each word is applicable to either of them. Dido has already (628-9) described her experience in words that might have been applied to that of Aeneas:

me quoque per multos similis fortuna labores iactatam hac demum uoluit consistere terra

and she is going on to apply errantem and errores to Aeneas (753-6):

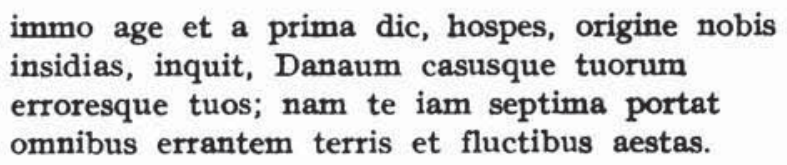

The moon and sun then of 742 might symbolise Dido and Aeneas but there is no compelling reason for supposing that they do and if this supposition brings too many difficulties in its wake, they might be taken as reasons for denying that Virgil intended any symbolism in these lines. The first difficulty is that $743-4$ seem to be outside the symbolism. Yet if there is symbolism in 742 , the reader is tempted to search for further symbolism before giving up. In other words he has been at least momentarily misled and we ought not to attribute such a failure of art to Virgil if there is a good alternative explanation. Secondly, if solis in 742 symbolises Aeneas, it would be awkward not to take soles in 745 as doing the same. On the other hand it would be just as awkward to take it as doing so, since it is plural and has the adjective hiberni attached to it.

Thirdly, what is the symbolic meaning of the words:

quid tantum Oceano properent se tingere soles hiberni

supposed to be? Pöschl wants them to indicate Aeneas' eager longing for Dido but could they not equally well be taken to indicate that Aeneas is eager to be off? In support of that interpretation could be quoted (IV 309-IO):

quin etiam hiberno moliris sidere classem el mediis properas Aquilonibus ire per altum. 
On this interpretation Dido and Aeneas are symbolised in 742 with shared experience but in 745-6 as in opposition with Aeneas eager to be off and Dido seeking to hold him back. These various doubts and difficulties suggest that it is better to drop the idea that there is any symbolism in these lines.

\section{III}

Two other interpretations may be mentioned. Segal ${ }^{1}$ sees significance in the fact that Iopas was taught by Atlas, the once rebellious Titan. As a consequence, Iopas' song is supposed to emphasise the irregularities and blemishes in nature and give a picture of it bedimmed by suffering and change where the will of Jupiter seems momentarily obscured. Against this it may be pointed out that the picture Virgil gives is largely that of the passage already quoted from Georgics II. Virgil could of course be giving the lines a different meaning in a different context but hardly the meaning Segal wants him to give them, since certain of the lines from the Georgics passage, which do emphasise the disorder of nature, have actually been removed from the present passage, as I pointed out above. Moreover in the Aeneid Atlas is not represented as 'a harsh outlaw', as Segal would have it. In VIII 138-4I, where Aeneas is demonstrating to Evander that they are related, Aeneas traces both their lines back to Atlas. Other and better reasons can be found for making Atlas Iopas' teacher ${ }^{2}$.

$\mathrm{Kranz}^{3}$ thinks Virgil is trying to portray Dido's court as foreign luxurious, oriental and alien to Roman ideals. So Iopas is crinitus (though so is Apollo in IX 638), plays on a golden lyre and the sun and moon of 742 represent foreign gods. But how is the reader supposed to know that the sun and moon represent foreign gods? They do not in the Georgics passage and if this is Virgil's intention, why a few lines before in 73I-4 does he represent Dido as praying to Jupiter, Bacchus and Juno? The picture is the same in Book IV, e. g. in 58-9. The court of Dido is luxurious but is this not simply a conventional and in the circumstances unrealistic ${ }^{4}$ picture of the court of a great

1 C. Segal, "The Song of Iopas in the Aeneid", Hermes 99, 1971, p. $336 \mathrm{f}$.

2 They may be found in Austin on $174 \mathrm{I}$. Some good observations on the role of Atlas in the Aeneid are contained in H. M. Currie, Proc. Virg. Soc. 2, 19621963, p. 20 .

- W. Kranz, "Das Lied des Kitharoden von Jaffa", $R h M$ 96, 1953, p. 3of.

- E. $g$. it seems unlikely that a band of refugees, surrounded by enemies, would have built a splendid palace for their queen or a temple complete with murals before finishing their city walls! 
queen? The Trojans themselves are not represented as examples of ancient Roman simplicity. Troy itself was a city of splendour (cf. II $448,503-4,763-6)$ and the Trojans carry some of its treasures with them. When Orontes ship is wrecked, the treasures of Troy are seen amid the waves (I II9). Dido receives magnificent gifts (I 647-55), so does Latinus (VII 243-8), whilst in Book V there are splendid prizes for the competitors in the games. In IV $215-6$ Iarbas sneers at the effeminate ways of the Trojans and so does Numanus in IX 598-620. In short there does not appear to be any contrast intended on these points at least between the Trojans and the Carthaginians, and Dido, far from being the Cleopatra-like figure Kranz would have her, is surprisingly very much like a Roman matron in her scruples about remarriage.

Segal in general follows Kranz but suggests some further points. He tries to discount the speech of Iarbas because it was made in a passion whilst as for that of Numanus, "no less a personage than Ascanius avenges the insult». But charges are not necessarily untrue because made in a passion nor are they refuted by killing the man who makes them. Segal sees the Song of Iopas as evidence of Carthaginian decadence for two further reasons. First, it contains unroman speculation in Greek science. But surely the author of the Georgics II passage could not without hypocrisy put this forward as a sign of decadence, especially when so much of Book VI is based on Greek speculation, and would Virgil's sophisticated readers have accepted it if he had? Secondly, Segal thinks the very presence of music also indicates decadence. This, he argues, is the only appearance of music in the Aeneid and their music is one of the signs of decadence Numanus taunts the Trojans with. Now it is true that there is not much mention of music in the Aeneid - though it might be asked where else Virgil needed to bring it in - but this is not in fact the only reference to it. In Book VI Misenus is killed for presuming to challenge a Triton to a musical contest and Misenus is described there (I69) as fortissimus heros. In Book IX (774-7) there appears

$$
\begin{aligned}
& \text { amicum Crethea Musis, } \\
& \text { Crethea Musarum comitem, cui carmina semper } \\
& \text { et citharae cordi numerosque intendere neruis, } \\
& \text { semper equos atque arma uirum pugnasque canebat }
\end{aligned}
$$

Also there is need to look more closely at Numanus' taunt. It is not music in general Numanus taunts the Trojans with but music of a particular kind (IX 6r7-20): 


\begin{abstract}
o uere Phrygiae, neque enim Phryges, ite per alta Dindyma, ubi adsuetis biforem dat tibia cantum, tympana uos buxusque uocat Berecyntia Matris Idaeae; sinite arma uiris et cedite ferro.
\end{abstract}

Numanus, like Plato in the Republic, is only attacking a particular

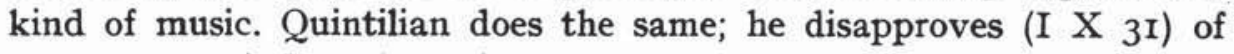
decadent music but gives his approval to that qua laudes fortium canebantur, quaque ipsi fortes canebant. Indeed there is plenty of evidence ${ }^{1}$ that in the good, old days Roman boys were taught to sing ballads, either accompanied on the pipe or unaccompanied, after dinner. Cicero says (De Oratore III 87): at Numerius Furius, noster familiaris, cum est commodum, cantat; est enim paterfamilias, est eques Romanus; puer didicit quod discendum fuit. Apart from the fact that it conformed to Homeric custom (did the Romans think that decadent?), Iopas' performance as described was not so different from what had gone on at Rome in the past that it was likely to convince Virgil's readers of Carthaginian decadence.

T. E. KINSEY

University of Glasgow

Glasgow (Scotland)

1 Cf. Cic. TD I 3. Other references are given by ' $\mathrm{T}$. W. Dougan in his note on that passage in his edition, Ciceronis Tusculanae Disputationes, Cambridge, 1905 . 